Arch. Tierz., Dummerstorf 45 (2002) 6, 557-563

University of Veterinary Medicine, Košice, The Slovak Republic

ANTON HVOZDIK, JANA KOTTFEROVÁ and JORGE da SILVA ALBERTO

\title{
Ethological study of social behaviour of pigs from the point of view of housing restriction
}

\begin{abstract}
Summary
Investigations were carried out to observe predetermined forms of social behavior in pigs affected by environmental space restriction. Pens of floor area $3.6 \mathrm{~m}^{2}, 6.8 \mathrm{~m}^{2}$, and $29 \mathrm{~m}^{2}$ were used in the study. The experimental programme included 150 piglets from 15 litters with their mothers (10 piglets in one litter). In each cage five piglets with their mother were placed. The animals were observed from the day they were born up to the age of 6 weeks and the forms of social behavior were recorded each day 24 hours during the mentioned weeks. The piglets were weaned in the $6^{\text {th }}$ week of their life and were mixed by the previous categorization of piglets. Ethological observations continued by initial way just before weaning. The piglets housed in smaller pens $\left(3.6 \mathrm{~m}^{2}\right.$ and $\left.6.8 \mathrm{~m}^{2}\right)$ showed abnormal development of agonistic behavior in terms of increased level of aggression (Mann-Whittney $U$ test, $p<0.05$ ). In these pens we registered high frequency of cephalic attacks to dorsal, cephalic and anogenital regions of piglets which remained unchanged after 3 weeks of the experimental programme (Wilcoxon, $\mathrm{p}<0.05$ ). The development of social learning in the experimental animals was retarded and the development of agonistic behavior and social hierarchy did not re-establish itself even after the $2^{\text {nd }}$ week of the experiment following the dislocation of piglets to the housing space $\left(29 \mathrm{~m}^{2}\right)$.
\end{abstract}

Key Words: piglets, social behavior, agonistic behavior, area restriction

\section{Zusammenfassung}

Titel der Arbeit: Ethologische Studie des sozialen Verhaltens von Saugferkeln bei eingeschränkter Buchtenfläche

Beobachtet wurde das Sozialverhalten von Saugferkeln in Abhängigkeit von einer unterschiedlichen Buchtenfläche. Diese betrug 3,6, 6,8 bzw. 29,0 $\mathrm{m}^{2}$. In die Untersuchungen waren 150 Saugferkel von 15 Landrasse x Large White Sauen mit je 10 Nachkommen einbezogen. Die Ferkel wurden von der Geburt bis zum Alter von 6 Wochen, ihrem Absetzalter, über den Zeitraum von $24 \mathrm{~h}$ mittels Videoaufnahmen beobachtet. Die in kleineren Buchten gehaltenen Ferkel zeigten ein signifikant größeres aggressives Verhalten. Dies bestand in Kopfattacken auf die Kopf-, Rücken- und Afterregion der Buchtengefährten. Die Entwicklung der sozialen Lernfähigkeit der Versuchstiere in den kleineren Buchten war zurückgeblieben. Auch nach der am Ende der 2. Lebenswoche erfolgten Umsetzung der Tiere in größere Buchten $\left(29,0 \mathrm{~m}^{2}\right)$ hatte sich noch keine soziale Hierarchie herausgebildet und die Tiere zeigten weiterhin ein stärkeres Aggressionsverhalten.

Schlüsselwörter: Ferkel, Sozialverhalten, Aggressionsverhalten, Buchtenflächenbeschränkung

\section{Introduction}

Social behavior of domesticated animals including the pigs is one of the basic criteria and presumptions of their normal or abnormal existence in the housing environment. In these circumstances, environmental factors are the basic imperative of adaptative or maladaptive responses of animals with corresponding health, reproductive, productive, and ethical consequences (LUESCHER et al., 1989).

Despite its five thousand years history, the domestication process with its adaptative character involves continuous ambivalence between species-specific and individual behavior of pigs and the artificial conditions of modern intensive housing. This poses a 
constant risk of development of abnormal forms of pig behavior and reduced welfare. This applies particularly to pigs which, from the point of view of ethological and zoopsychological characteristics, exhibit increased levels of excitability, tendency to intraspecies aggresivity, and psychosomatic prevalence (PSE syndrome) (HVOZDÍK, 1983).

Therefore it is not surprising that social interactions between pigs and their environment are the subject of constant professional interest from various angles. This includes studies focused on the influence of rearing with or without bedding on social activities of pigs which showed that the presence of bedding is important for the stability of social activities of animals in the group (PUTTEN and DAMMERS, 1976; SCHMIDT and ADLER, 1981). In the recent period, considerable attention has been paid to stereotype behaviour of pigs resulting from sensory deprivation (BROOM, 1996; HVOZDÍK, 2000). The study of agonistic behaviour of pigs, as an intraspecies conflictogenic behaviour including the aggresivity, is important in relation to their environmental status. From this point of view, canibalism in all its forms (cronism, auriclar, and caudal forms, etc.) is one of important categories of anomalous agonistic behavior (HVOZDÍK et al., 2001).

The influence of the environment on early ontogenesis of piglet behavior (imprinting, weaning) decides the normal behavioral patterns of adult animals. The maternal behavior of sows, as one of the most important social forms, completes the picture of the importance and complexity of the early development of animals (HVOZDÍK, 1997; RUSHEN et al., 1994).

When setting the objective of our experimental study, we started from the hypothesis about the negative influence of environmental deprivation, induced by various experimental space variables, on the social behavior of piglets. We were interested in the level of agonistic behaviour, its development under normal or abnormal conditions as a basic precondition of the development of social hierarchy and thus also the sociability of piglets.

\section{Materials and Methods}

The experimental behavioral programme included 150 piglets from 15 litters together with their mothers. The animals originated from a breeding herd and were reared under standard intensive conditions at the respective farm. They were of $F_{1}$ (LA x BU) Landrace and Large White breed. The selection of piglets and their mothers was a random sampling, piglets were equally divided in each litter by their sex, as well as by their birth weight. Males were castrated at 14 days of age. Within $24 \mathrm{~h}$ after the farrowing, the piglets were marked with obstetric dye of human type and weighed. They were housed in three types of pens with floor areas of $3.6 \mathrm{~m}^{2}, 6.8 \mathrm{~m}^{2}$, and $29 \mathrm{~m}^{2}$. In the first two pens, the mothers could not more freely, but in the third case they could. The piglets were weaned in the sixth week of their lives. Ethological observation has continued the same way as before weaning. Piglets in all three pens were supplied with bedding, which was changed every day. The experiment was carried out in May - June.

Five litters had been localized in the floor area of $29 \mathrm{~m}^{2}$, each one of them with 10 piglets and their mothers. A similar number of animals were in the pens of $3.6 \mathrm{~m}^{2}$ and $6.8 \mathrm{~m}^{2}$. On the $3^{\text {rd }}$ day after the birth, predetermined forms of behaviour, i.e. social interactions of all experimental animals, were recorded with video camera over 24 
hours $(100 \%)$. Agonistic interactions as intraconflict (in case of piglets they were considered as fighting/playful activities) behaviour of two piglets were made from the ethological observation each day 24 hours, recorded on video camera throughout the 6 weeks. Piglets were weaned in the $6^{\text {th }}$ week of their life and were mixed by the initial categorization into the pen of $29 \mathrm{~m}^{2}$ and were observed by the same methods.

Social interactions of the contact type were defined as forms of behaviour specified by three seconds before the physical contact and three seconds after the last physical contact. The 10s time from the last physical contact presented the possible occurrence of new, registered social activity of the animals. The videotape was viewed in slow motion repeatedly and each time unit (seconds) of social behaviour of piglets was evaluated over $24 \mathrm{~h}(100 \%)$.

Statistical methods: For statistical evaluation was used Mann-Whittney U test, $\mathrm{p}<0.05$ and Wilcoxon, $\mathrm{p}<0.05$.

Summarized forms of social interactions of piglets provided the following ethogram:

- Nasal contact - each contact of the nasal part of an animal with any part of the body of another animal

- Frontal standing position - two standing piglets facing each other

- Locomotion - intended mutual approach of two piglets

- Ambivalent activity - mutual approach of two piglets followed by immediate retreat

- Standing - immobile position of piglets without behavioral expression

- Cephalic interactions - horizontal or vertical cephalic contacts of various intensity and quality (striking, pushing, and others).

The following categories were used:

1. Biting

2. No biting, the attack is oriented to various bodily parts of another piglet

3. Attack oriented to a genital and dorsal regions of another piglet

4. Attack oriented to cephalic and scapular regions of another piglet.

\section{Results}

At the end of the first week the cephalic interactions were most frequent in the pens with a floor area of $6.8 \mathrm{~m}^{2}$ and $29 \mathrm{~m}^{2}$. Maximum frequency of cephalic interactions in the pen $\left(29 \mathrm{~m}^{2}\right)$ was recorded in the $2^{\text {nd }}$ week of observation (Fig. 1). During the first week the number of cephalic manifestations was higher than in that with the floor area of $3.6 \mathrm{~m}^{2}$ (Mann-Whittney U test; MWU; $\mathrm{p}<0.05$ ). The difference in the forms of behaviour between pens $6.8 \mathrm{~m}^{2}$ and $3.6 \mathrm{~m}^{2}$ was significant in the second half of the first week (MWU, $\mathrm{p}<0.05$ ). The cephalic interactions of piglets in all the pens decreased between weeks 2 and 5 of ethological monitoring (Wilcoxon test, $\mathrm{p}<0.05$ ). Cephalic interactions of piglets of the "biting" type were most frequent in the pens with floor area of $6.8 \mathrm{~m}^{2}$ and $3.6 \mathrm{~m}^{2}$ in comparison with a rearing environment $(29$ $\mathrm{m}^{2}$ ). In the latter pen this form of social behaviour declined rapidly in the course of observation. During the $6^{\text {th }}$ week only $5 \%$ of piglets reared in this pen exhibited this cephalic behaviour while in the $6^{\text {th }}$ week of ethological monitoring 25 to $36 \%$ of those kept in pens $6.8 \mathrm{~m}^{2}$ and $3.6 \mathrm{~m}^{2}$ showed these behavioural activities (Fig. 2). 


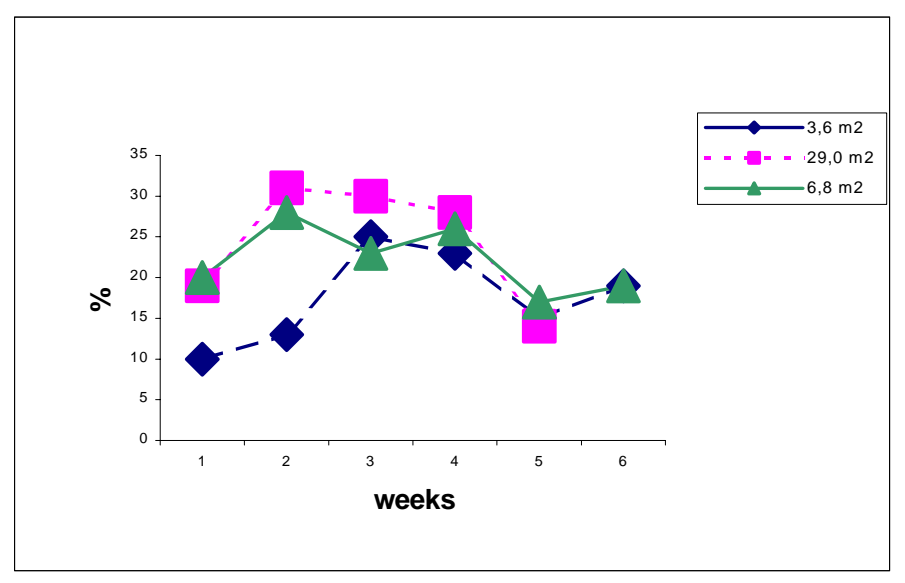

Fig. 1: Temporal Percentage Expression of all Cephalic Interactions Observed in the Study

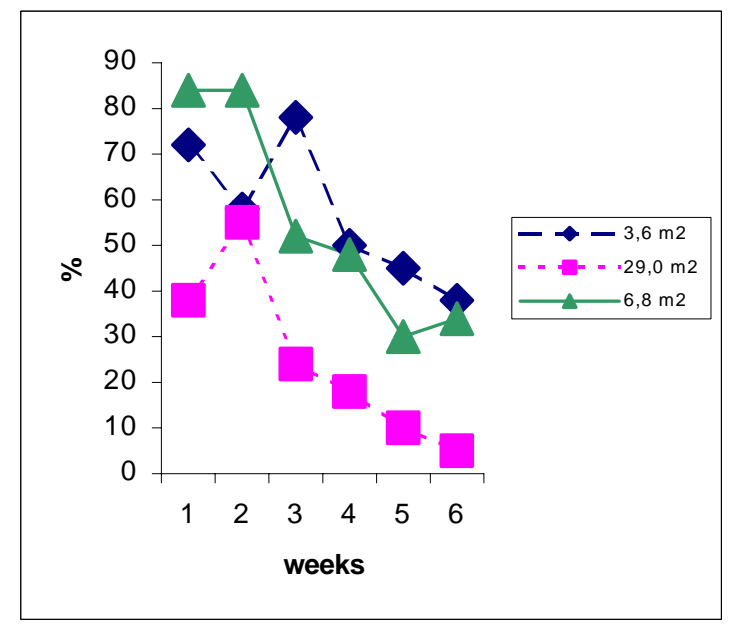

Fig. 2: Percentage Expression of all "Biting" Cephalic Interactions

In pens of $29 \mathrm{~m}^{2}$ and of $6.8 \mathrm{~m}^{2}$ the cephalic attacks were oriented mainly to the back and declined with age. Such manifestations were recorded only in $2 \%$ of piglets in the pen $29 \mathrm{~m}^{2}$ during the $5^{\text {th }}$ week and also in the $6.8 \mathrm{~m}^{2}$ pen during the $6^{\text {th }}$ week of our ethological observation. In this week, $15 \%$ of piglets kept in the $3.6 \mathrm{~m}^{2}$ pen were involved in cephalic attacks to dorsal and anogenital parts of other piglets (Fig.3).

The behaviour form "frontal standing" was recorded more frequently in the standard pen in comparison with that of floor area of $3.6 \mathrm{~m}^{2}$ (MWU, $\mathrm{p}<0.05$ ) (Fig. 4). Only during week 6 of the experiment were significant differences in this form of behaviour observed in comparison with pens $6.8 \mathrm{~m}^{2}$ and $3.6 \mathrm{~m}^{2}$ (MWU $\mathrm{p}<0.05$ ). During the $5^{\text {th }}$ week of the experimental programme the form of "frontal standing" was more apparent in the standard pen $\left(29 \mathrm{~m}^{2}\right)$ in comparison with the $6.8 \mathrm{~m}^{2}$ pen (MWU p $<0.05)$. This form of social interaction has been frequently classified as behavioural signaling of the "offensive threat" before the aggressive attack of animals in a dyad (JENSEN, 1994). This social exploration is an important factor of agonistic behaviour (aggressive behaviour, offensive, defensive threat, retreat, flight) which marks the onset of establishment of social position of two individuals in their social interaction. 


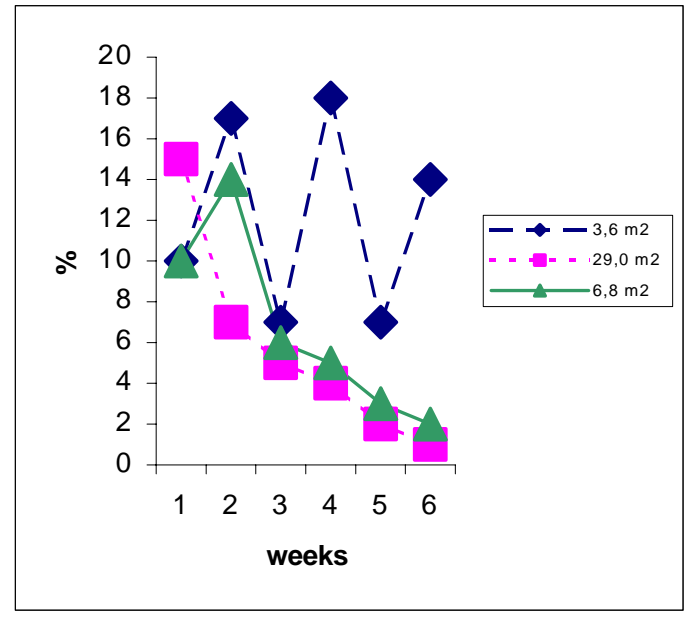

Fig. 3: Percentage Expression of Cephalic Interactions Oriented to Dorsal and Anogenital Regions

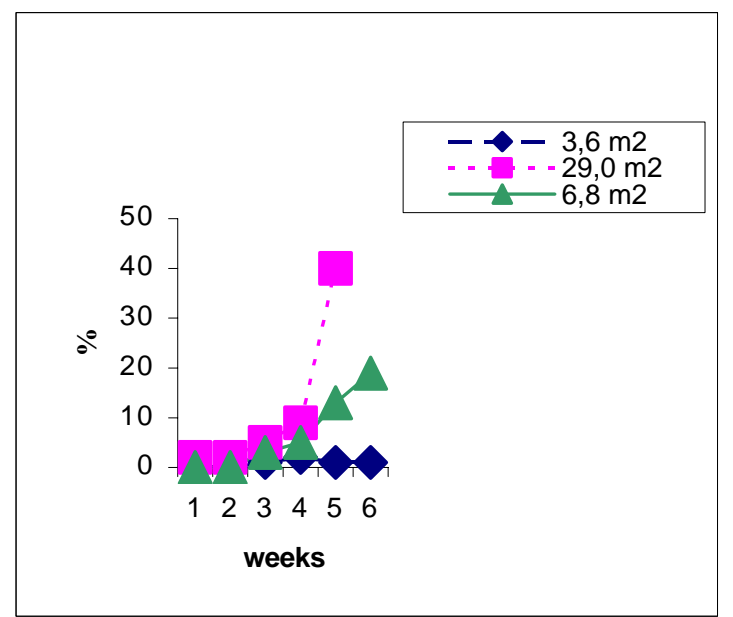

Fig. 4: Temporal Percentage Expression of all Observed Forms of Frontal Standing

Table

Percentage proportions of behavioral forms immediately preceding the cephalic interactions

\begin{tabular}{lccc}
\hline & \multicolumn{1}{c}{ Weeks } & $\mathbf{6}$ \\
\cline { 2 - 4 } Pen floor area & $\mathbf{1}$ & $\mathbf{4}$ & $6.3 \%$ \\
\hline $\mathbf{3 . 6} \mathbf{~ m}^{2}$ & & & $3.9 \%$ \\
Nasal contacts & $26.6 \%$ & $11.0 \%$ & $15.5 \%$ \\
Frontal standing & - & $4.3 \%$ & $32.4 \%$ \\
Locomotion & $7.3 \%$ & $12.3 \%$ & $3.8 \%$ \\
Standing & $33.0 \%$ & $36.3 \%$ & $29.5 \%$ \\
\hline $\mathbf{6 . 8} \mathbf{~ m}^{2}$ & & & $7.6 \%$ \\
Nasal contacts & $18.9 \%$ & $10.8 \%$ & $25.4 \%$ \\
Frontal standing & - & $8.8 \%$ & $4.4 \%$ \\
Locomotion & $7.0 \%$ & $12.2 \%$ & $37.8 \%$ \\
Standing & $44.3 \%$ & $35.3 \%$ & $4.4 \%$ \\
\hline $\mathbf{2 9} \mathbf{~ m}^{2}$ & & & $31.1 \%$ \\
Nasal contacts & $11.1 \%$ & $6.8 \%$ & $9.2 \%$ \\
Frontal standing & $2.8 \%$ & $8.8 \%$ & $49 \%$ \\
Locomotion & $4.6 \%$ & & \\
Standing & $50.0 \%$ & & \\
\hline
\end{tabular}


The Table shows the percentage proportion of the behavioural forms observed immediately before cephalic interactions in the course of weeks 1 and 4, and 6 of the experiment. During the weeks 5 and 6, similar to the previously described forms of cephalic interactions, the intensity of "frontal standing" decreased in pens $6.8 \mathrm{~m}^{2}$ and $29 \mathrm{~m}^{2}$ but not in the $3.6 \mathrm{~m}^{2}$ pen.

\section{Discussion}

Our results allow us to deduce several basic facts. The agonistic behaviour of piglets in the pens of smaller floor area $\left(6.8 \mathrm{~m}^{2}\right.$ and $\left.3.6 \mathrm{~m}^{2}\right)$ did not develop in the normal way, i.e. through appropriate communication, social-signaling behaviour resulting in subsequent social hierarchy. Of individual forms of agonistic behaviour we observed only a high level of aggressive behaviour. In this case the environmental deprivation of piglets induced in them also social deprivation. In this association BARNETT et al., (1987) indicated that these deprivation syndromes negatively affect the social relationships mother-piglets, and vice versa. MENDL et al. (1993) observed in their experiments that housing restrictions in pig rearing results in a significant occurrence of stereotypic behaviour which negatively affects their physiological parameters and welfare. This involves the hypothalamo-pituitary-cortical reaction to chronic stress. The cephalic activities of piglets observed in our study can also be classified as stereotypic forms of behaviour.

Piglets reared under restricted conditions lose their ability for social learning (sexual behaviour, exploration, etc.) (BROOM, 1993). This was proved also by our results when negative experiences such as fixed unwanted learning caused the frequency of cephalic attacks of the "biting" type, observed in pens of small dimensions, showed no significant change after the second week, and even though after velocating to the pen of $29 \mathrm{~m}^{2}$. Similarly, the social learning of the type of head-head and head-shoulder area contacts was absent in the pens with the smaller floor area. We did not record the gradation of the retarded development of agonistic behaviour in the $3.6 \mathrm{~m}^{2}$ pen after the $2^{\text {nd }}$ week of the experiment. The infantile social encounters of piglets persisted up to the 4 weeks and in some cases always up to 6 weeks of the experimental programme. The sociability of individuals as their ability to respect the social regimen within the group was disturbed in the experimental piglets due to deviant development of social hierarchy.

The results obtained indicate that the housing space in the respective farm for intensive rearing of piglets should consider the requirements of floor area and adjust the stocking density of piglets. With respect to the objective of our study we were able to prove the development of a high level of agonistic behaviour in these animals due to deprivation state determined by restricted housing space.

\section{References}

BARNETT, J.L.; HEMSWORTH, P.H.; WINFIELD, C.G.:

The effects of design of individual stalls on the social behaviour and physiological responses related to the welfare of pregnant pigs. Appl. Anim. Behav. Sci., 19 (1987), 133 - 142

BROOM, D.:

The effects of social and physical environment on social behaviour in farm animals. $3^{\text {rd }}$ Joint Meeting, Proceedings of the International Congress on Applical Ethology, Berlin (1993), 213 - 222

BROOM, D.M.:

A review of animal welfare measurement in pigs. Pig - News - Information 17 (1996), 4 
HVOZDÍK, A.:

Abnormal behaviour of pigs (In Slovak). Veterinářství 33 (1983), 534 - 562

HVOZDÍK, A.:

Ethological study of social behaviour of pigs after negative experience in early ontogenesis. Folia Veterinaria 41 (1997), 131 - 134

HVOZDÍK, A.:

Cognitive ethology and stereotypic behaviour of animals (In Slovak). Slov. vet. čas. 25 (2000), 33 - 36

HVOZDÍK, A.:

JENSEN, P.:

Cronism in pigs (In Slovak). Veterinářství 41 (1991), 15

Individual variation in behaviour - noise or functional strategies? Proceedings $-28^{\text {th }}$ International Congress of the ISAE, Foulum, Demark (1994), $93-101$

LUESCHER, V.A.; FRIENDSHIP, P.R.M.; LISSEMORE, K.D.; McKEOWN, D.B.:

Clinical ethology in food practice. Appl. Anim. Behav. Sci. 22 (1989), $191-214$

MENDL, M.T.; BROOM, D.M.; ZANELLA, A.J.:

The effects of three types of dry sow housing on sow welfare. In: E. COLLINS, C. BOON (eds). Livestock environment. St. Joseph Mich. American Society of Agricultural Engineers (1993), $461-467$

PUTTEN, G. VAN; DAMMERS, D.:

A comparative study of the well - being of piglets reared conventionally and in cages. Appl. Anim. Behav. Sci., 2 (1976), $339-356$

RUSHEN, J.; PASILLÉ, A.M.; LADWIG, G.J.; FOXCROFT, G.:

Effects of stress on material behaviour in pigs. Proceedings $-28^{\text {th }}$ International Congress of the ISAE, Foulum, Denmark (1994), 35

SCHMIDT, M.; ADLER, H.C.:

Danish studies on behaviour of early weaned piglets : preliminary results. In: W. SYBESNA (eds). The Welfare of pigs. Martinus Nijhott Publishers, The Hague (1981), $211-223$

Received: 2002-04-04

Accepted: 2002-09-23

Autors address

ANTON HVOZDIK, DVM, PhD., JANA KOTTFEROVÁ, DVM, PhD., JORGE da SILVA ALBERTO, DVM

University of Veterinary Medicine

Komenského 73

04181 Košice

Slovak Republic 